\title{
Constraints Facing Teachers of Christian Religious Education in Using Life Approach in Secondary Schools in Nairobi East District in Kenya
}

\author{
Ngunju Alice Wambui \\ School of Education \\ Mount Kenya University

\section{Dr. Wycliffe Amukowa} \\ School of Education \\ Mount Kenya University \\ Email:kwamukowa@yahoo.com
}

Doi:10.5901/ajis.2013.v2n2p353

\begin{abstract}
The strategy used in teaching and learning has a bearing on effectiveness and quality of education offered. The integrated Christian Religious Education (CRE) lays emphasis on what is known as the life Approach strategy of teaching and learning. Although most CRE teachers are academically trained and have professional competencies, they encounter a number of challenges in the use of life approach in teaching the subject. The purpose of this study to identify the ways in which the various constraints facing teachers of CRE in the use of life approach can be adequately addressed.
\end{abstract}

Keywords: Teaching, Education, Constraints, Learning

\section{Introduction}

Review of literature on the History of education in Kenya indicates that there have been many curriculum changes as evidenced in the various education commission Reports notably, the Kenya Education commission (1964) headed by professor $\mathrm{H}$. Ominde which brought extensive changes in education practice of that time, the National Committee on Educational policies(Gachathi Report, 1976 and Presidental working party on the second university (Mackay report,1982) which led to the introduction of the 8-4-4 education system in Kenya, which was implemented in 1985. The changes have been made in a deliberate effort towards the provision of meaningful and relevant education to the Kenyan society, because curriculum design is developed with awareness of its philosophical position and Links to what society believes is important for children to learn (Golby, 1983). Purpose of the society oriented curriculum is to serve the needs of the society as advocated for by Kenya Education commission report (1964).

The 8-4-4 education system entails 8 years of primary four years secondary education and 4 years University education .The 8-4-4 system is characterized by an integrated (broad-fields) Curriculum design approach. The integrated approach led to the fusing of some hitherto related subjects that had been taught separately, or infusion came about by fusing different themes, topics or areas of learning that were more or less considered separate subjects and examined by separate studys in the old system to be within the same discipline. The new curriculum lay emphasis on what is known as the life Approach experiential strategy of learning and teaching, in which the experiences of the learner forms the basis for introducing new concepts and makes the learner the starting point. This approach calls for teaching from the concrete to the abstract; form simple to the complex, hence has its approach in learner centered education.

Like any new curriculum innovation, the 8-4-4 programme presented new challenges to the teachers for it required new knowledge and skills, and methodology to implement it effectively. (Oluoch, 1982). It also required the in servicing of teachers to keep abreast of the new changes in teaching-learning strategies. At the school level, implementation of these changes is considered central to the teacher's role, and the importance of implementation cannot be overemphasized and so is teacher participation in the implementation process of the curriculum in their schools. 
After Independence, attempts were made to make education relevant to the needs of the Kenyan society. Various educational commissions were appointed, notably the Ominde commission (Kenya education commission) of 1964, which emphasized the co-operation of religious bodies in the matter of religious instruction, and advocated the creation of ecumenical syllabuses, in which religious instruction was treated as academic subject on educational lines. The Education Act of 1968 which recommended among many things the sponsors right to prepare and recommend syllabuses books and other teaching and learning resources used for religious instruction.

In respect to the teaching of CRE, in schools, a joint church panel was set up in 1968 to work on a syllabus which could be more relevant to the Kenyan situation. A committee of Catholics and Protestants from Kenya, Malawi, Tanzania, Uganda and Zambia under the title "Rubaga workshop" prepared a syllabus 223 Christian living today in 1970 with an aim of enabling students to grow towards a responsible maturity. This syllabus emphasized life related themes.

The second CRE panel met in 1980 to review the syllabus developed after independence and the panelists observed that aims of CRE were biblical or Christian centred and that what the learner was taught was pre-determined and hence the learner had little say on what was taught. The panel therefore recommended that a new syllabus which would move from Bible themes to Life Themes developed. This prompted the syllabus Review report (1980) which was to emphasize on a more learner centred approach to teaching of CRE. At this period, the Government was working on an overhaul of the education system and restructured. This resulted to the Mackay report which placed CRE as compulsory subject in Form I and II and optional in form 3 and 4 in group IV Social sciences (Humanities) together with History and Geography.

The new 8-4-4 education system was to replace the 7-6-3 system and entailed 8 years primary education, four years secondary and 4 years University education. The 8-4-4 emphasized on an integrated approach rather than subjectcentred approach. As regards CRE, the emphasis was on Life approach, where teaching starts from the learners experience and present situation thereby letting them arrive at a religious understanding of the experiences. With regard to $\mathrm{CRE}$, different themes in the History, African religious Heritage and Christian approaches to social and ethical issues were almagamated or fused into one common Christian religious education programme, the integrated CRE, and are examined by two compulsory studys.

Many features of our present day religious education is derived from its history. The history of C.R.E has its roots in the synagogues tradition of the Jews at the time of Jesus. The kind of religious education that was taught in the synagogue influenced the early Christian catechumenate, both in its rituals, its doctrinal and moral educational content. The core of its content, originally a profession of faith in Jesus Christ son of God and saviour, soon became a profession of faith in the blessed Trinity and the church, gradually; the Creed grew acquiring ever more details and so became a sort of treatise of the Christian faith. Much of the moral educational content of early religious education came directly from the Old Testament and New Testament, the rituals too derived from Jewish tradition.

Christianity also took root in the Greek and Roman cultures around the Mediterranean region and with it, religious education also began to take on Greek and Roman cultural features. During the European Middle Ages, religious education saw recognition in the monasteries, abbeys and cathedral schools, and at this time Christian tradition became an integral part of European culture. It was this European cultured form of Christianity that was spread throughout the world during the missionary period of the $19^{\text {th }}$ and 20th centuries. This Early missionary education became the main basis for the school system in colonial Kenya, with a firm insistence on the European cultural forms of morality and worship. Originally religious education was the core subject of the missionary curriculum and other subjects were clearly in supportive role, and religious education was the only subject in missionary schools that was not open to discussion and was taken as the most important subjects.

The aims and objectives of Religious education by then were either biblical or Christian centred, and used confession (missionary approach by then, the aims and objectives were predetermined on what the learner should study and came out, leaving him with very little choice. However, things changed drastically as curriculum thinkers especially in Britain in the 1960 and 1970s started asking the justification of the subject's presence in the school time-Table. These curriculum thinkers were no longer content with a theological rationale as used to be the custom. They started demanding for a sound educational rationale. Under the influence of philosophy and psychologists like John Piaget, they argued that every subject in the curriculum was to be justified only on the grounds that it contributed significantly to the child's general education and more emphasis on the importance of experience in the learning process. Thus, advocated learnercentered learning in contrast to subject centred learning. It is against this background that this intends a discussion on the constraints teachers of CRE face in the use of life approach which as a move from traditional methods of teaching which were subjected centered to a learner- centered approach with emphasis on learners experience in the learning process. 


\section{Theoretical Framework}

The theoretical framework of this study is based on Jerome Bruner's Discovery learning theory (Jerome, 1966), who argued that the teachers role must be; to create situations in which students can learn on their own rather than provide prepackaged information students, Bruner states:

We teach a subject to produce the little living libraries on the subject rather than to get a student to think for himself to consider maters as a historian does, take part in the process of knowledge getting. Knowing is a process not a product (Bruner, 1966.72).

The discovery learning approach stresses the importance of students learning independently of the teacher, an approach seen as an important supplement to more structured teaching centered approach relies heavily on packaged information to students should not be passive audiences. In order to foster positive transfer of learning students should actively be involved in the learning process. This participation should be through discussions, experiment projects work field work, social action projects, field trips, role play or socio - drama or simulation methods.

The experiential methods aim at exposing students to the reality of life outside the classroom. Jerome (1966) Laments that school tends to "shield" young people from the reality of this world. The school is supposed to be a preparation for life yet the school seems to keep school students away from life. The above is supported by information processing theory. Research on human memory has helped teach theorists to describe the process by which information is remembered and forgotten. If students are bombarded with too much information at once, they may have difficulty learning any of the information at all. Learners may forget much of the information that they are taught due to exposure to too much information over a limited duration of time. The underlying phenomenon in Jerome's (1966) theory is the fact that learners should learn from experiences and pick up attitudes, values and beliefs. This emphasizes that learners should be active and actively involved in the learning process as underscored in the diagram below.

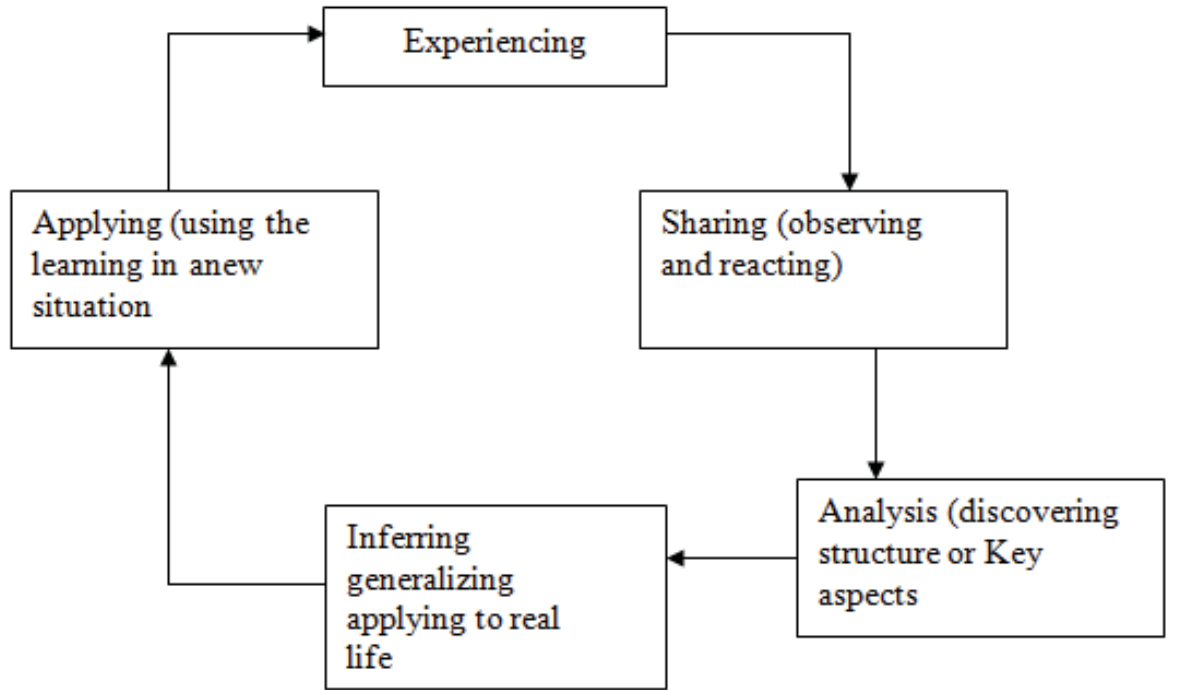

Fig. 1: Conceptual framework showing the experiential learning cycle (Source: Based on "Role playing" by J. Jones and in Pfeiffer, 1979, San Diego C.A University Associates)

\section{Methodology}

This study elicits information from teachers and students in various schools based on a descriptive survey. Polit, (1995) asserts that the purpose of descriptive survey is to observe describe and document aspects of a situation as it naturally occurs. It attempts to describe what was or what is in a social system such as a school. It is on the basis of these characteristics of descriptive research that challenges facing teachers of CRE in using life approach in secondary schools are assessed. A total of 14 secondary schools in Nairobi East district that offer CRE, up to form 2 and in form 3 where 
students, take the subject as an option form the target population .These 14 schools have a total population with an average of 3,600 students out of which 360 participated. From each school 18 students were randomly sampled 9 from each class using the lottery technique. Out of the 14 teachers participating 9 teachers were used for classroom observation. 7 HoDs also participated. Questionnaires, interview guides and observation schedules were used in data collection.

\section{Teachers Academic and Professional Qualifications in Implementing Integrated CRE Using the Life Approach.}

The study sought to find out the academic and professional qualification of teachers implementing intergrated CRE using life approach. Bio data about the respondent's sex, Academic and professional qualification, teaching experience and teaching subjects was sought. This was considered important as it would give a hint on whether the respondents were academically and professionally qualified to teach integrated CRE using the life approach strategy.

Sex of the respondents was of particular importance to the researcher as it gave general information on who participated in the study. Table 1 shows the sex of the respondents

Table 1: Sex of the Teachers of CRE

\begin{tabular}{|l|c|c|}
\hline & Frequency & Percent \\
\hline Male & 3 & 21.43 \\
\hline Female & 11 & 78.57 \\
\hline Total & 14 & 100 \\
\hline
\end{tabular}

From the table the researcher found out that $78.57 \%$ of the teachers of CRE were females. Only $12.43 \%$ of the teachers were males.

Table 2: Teachers of CRE academic Qualifications

\begin{tabular}{|l|c|c|}
\hline & \multicolumn{2}{|c|}{ Academic Qualification } \\
\hline & Frequency & $\%$ \\
\hline Untrained Teacher & 1 & 7.1 \\
Diploma & 8 & 57.1 \\
Trained Graduate & 4 & 28.6 \\
Others & 1 & 7.1 \\
Total & 14 & 100.0 \\
\hline
\end{tabular}

The Results from table 2 revealed that $57.1 \%$ of CRE teachers are mainly Diploma teachers, while $28.6 \%$ are trained graduate teachers and $7.1 \%$ are untrained teachers.

\subsection{Professional Qualification of Teachers of CRE}

Professional training is a factor which affects teaching; hence this necessitated an investigation into the qualifications of the teachers. Figure1 presents details of the various professional qualifications. 


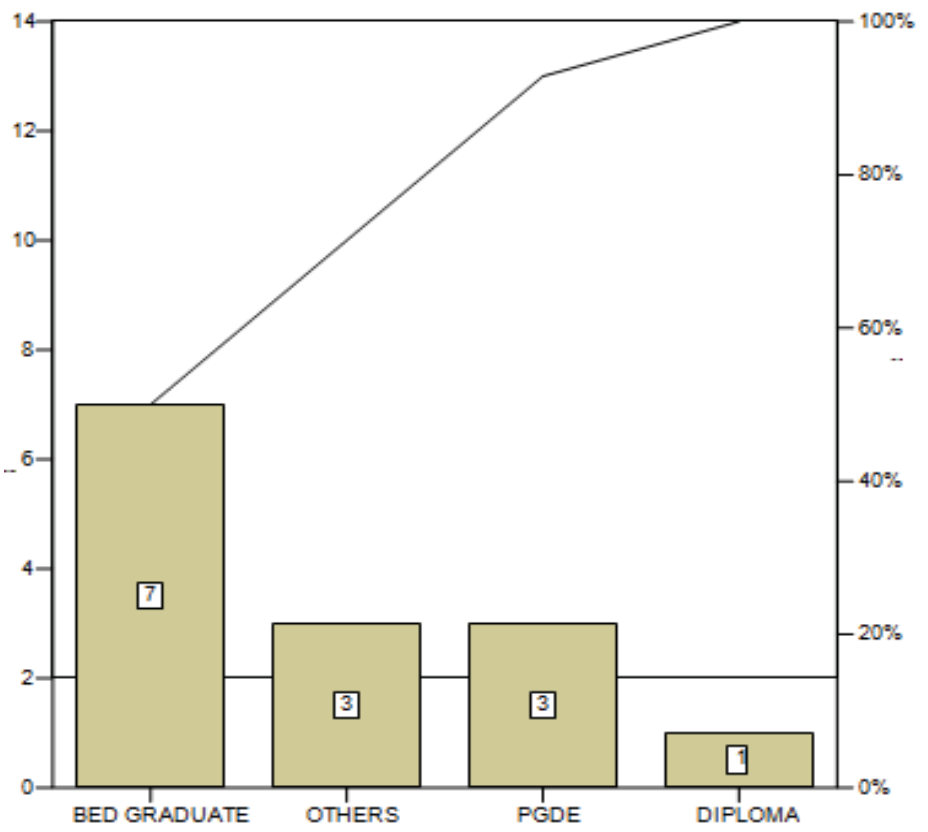

Figure 2. Professional Qualification of teachers of CRE

The figure 2 reveals that majority of the teachers $11(80 \%)$ are professionally qualified to teach integrated CRE our secondary schools, only $3(10 \%)$ of the respondents were not professionally qualified to teach.

\subsection{Professional Qualifications of Heads teachers}

The professional qualification of the Head teachers was sought, since they are key in assisting teachers of CRE to implement the course, by offering the required academic guidance. This is consistent, as Oliver (1969) noted that widespread involvement of teachers in curriculum implementation is effective under good leadership. Head teachers who are professionally sound are likely to sponsor teachers to development programmmes such as in service courses, workshops, and academic seminars for professional growth.

\subsection{Professional qualifications of Heads of Department (HODs)}

Table 3. HOD's Professional Qualifications

\begin{tabular}{|l|c|c|}
\hline & \multicolumn{2}{|c|}{ HOD's Professional Qualification } \\
\hline & frequency & $\%$ \\
\hline Diploma & 1 & 14.3 \\
Trained Graduate & 6 & 85.7 \\
Total & 7 & 100.0 \\
\hline
\end{tabular}

From the above tables, it can be inferred that most HODS in the sampled schools were highly qualified professionals and hence assisted teachers by offering/giving required guidance through their professional competences and support them in effective implementation of their course. 


\subsection{Teaching Experience}

In the questionnaire the teachers were further asked to state their teaching experience. Table 4 shows teachers' years of experience in teaching CRE at various levels of secondary education.

Table 4. Teachers' years of experience in teaching CRE at various levels (forms)

\begin{tabular}{|l|c|c|c|c|c|c|c|c|}
\hline & \multicolumn{2}{|c|}{ F1 Class Experience } & \multicolumn{2}{c|}{$\begin{array}{c}\text { F2 Class } \\
\text { Experience }\end{array}$} & \multicolumn{2}{c|}{$\begin{array}{c}\text { F3 Class } \\
\text { Experience }\end{array}$} & \multicolumn{2}{c|}{ F4 Class Experience } \\
\cline { 2 - 9 } & Count & $\%$ & Count & $\%$ & Count & $\%$ & Count & $\%$ \\
\hline LESS THAN & 3 & 21.4 & 3 & 21.4 & 5 & 35.7 & 3 & 21.4 \\
1 YEAR & 6 & 42.9 & 5 & 35.7 & 5 & 35.7 & 4 & 28.6 \\
2-5 YEARS & 2 & 14.3 & 3 & 21. & 2 & 14.3 & 4 & 28.6 \\
$6-10$ YEARS & 2 & 14.3 & 1 & 7.1 & 1 & 7.1 & 1 & 7.1 \\
$11-15$ YEARS & 1 & 7.1 & 1 & 7.1 & 1 & 7.1 & 2 & 14.3 \\
16- 20 YEARS & & & 1 & 7.1 & & & & 100.0 \\
OVER 21 YEARS & 14 & 100.0 & 14 & 100.0 & 14 & 100.0 & 14 & 100.0 \\
Total & & &
\end{tabular}

The teaching experience of teachers of CRE was considered important in influencing the teachers' approach to the subject. The information on which classes (forms) the teachers taught CRE revealed whether the teachers were aware of the CRE syllabus at various levels of secondary school. Table 4 summarizes the data on years of experience and the forms the teachers taught CRE.

From the table, it can be noted that $27.7 \%$ of the respondents had taught for a period of $2-5$ years in all levels of secondary education. $42 \%$ had taught in form $1,35.7 \%$ in form 2, 35.7\% in form 3 and in $28.6 \%$ in form 4 . It can be inferred from the table that most of the teachers had taught in all secondary school classes, giving them good interaction with integrated CRE syllabus and strategies used in implementing it.

\subsection{Teachers Preparedness}

The study sought to answer the research question on whether teachers of CRE are aware and familiar with curricular changes in secondary schools as relates to teaching strategies. Learning to a large extent depends on training of the teacher who in this case is the facilitator of learning and transmitter of knowledge. Both pre service and in-service training the teachers of CRE was considered. Information gathered from this section attempted to answer the research question: Are teachers of CRE fully or adequately prepared to teach integrated CRE using the life approach during pre-service and in-service?

\subsubsection{Pre-service Education Training in Teaching CRE using life Approach}

The research question under investigation was, are teachers of CRE fully or adequately prepared to teach using life approach during in service or pre-service was addressed.The 14 teachers of CRE to whom questionnaires were administered, were asked which subject they were specialized as shown in table 5.

Table 5: Teachers' subject specialization in pre-service training

\begin{tabular}{|l|c|c|}
\hline & \multicolumn{2}{|c|}{ Specialization } \\
\cline { 1 - 2 } & Frequency & $\%$ \\
\hline CRE/HIST & 7 & 50.0 \\
CRE/GEOG & 3 & 21.4 \\
CRE/KIS & 1 & 7.1 \\
CRE/ENG & 1 & 7.1 \\
OTHERS & 2 & 14.3 \\
Total & 14 & 100.0 \\
\hline
\end{tabular}


From the table, it can be noted that out of the 14 teachers who were interviewed $85.71 \%$ had CRE as their teaching subject, with $50 \%$ of the teachers specializing in CRE/History during pre service only $14 \%$ were not professionally specialized to teach CRE. This implies that majority of the teachers were specialized to teach CRE.

Results from the interview schedule with the Head Teachers revealed that only $25 \%$ were specialized to teach $\mathrm{CRE}$, the rest $75 \%$ did not specialize in teaching $\mathrm{CRE}$.

Table 6: Head Teachers Teaching Subjects

\begin{tabular}{|l|c|c|}
\hline \multirow{2}{*}{} & \multicolumn{2}{|c|}{ Teaching Subjects } \\
\cline { 2 - 3 } & Frequency & $\%$ \\
\hline Mathematics & 2 & 50.0 \\
Biology & 1 & 25.0 \\
CRE & 1 & 25.0 \\
Total & 4 & 100.0 \\
\hline
\end{tabular}

From the interview with the HOD's, it was noted that most were trained graduate teachers, while only $14.3 \%$ were Diploma teachers. This was a clear indicator that most of them were professional teachers.

Table 7: HOD's Academic Qualification

\begin{tabular}{|l|c|c|}
\hline \multirow{2}{*}{} & \multicolumn{2}{|c|}{ HOD'S Academic Qualification } \\
\cline { 2 - 3 } & Frequency & $\%$ \\
\hline Diploma & 1 & 14.3 \\
Trained graduate & 6 & 85.7 \\
Total & 7 & 100.0 \\
\hline
\end{tabular}

\subsubsection{Teachers Professional Training}

The teachers were asked to state whether the initially training adequately prepared them to teach the CRE course. Most of the teachers (64.3\%) the view that the training was insufficient and did not adequately prepare them to teach CRE. Only $7.1 \%$ viewed the training as sufficient. The minority $7.1 \%$ did not get any training at all, the rest $7.1 \%$ indicated that they were averagely trained.

Table 8: Teacher's Professional Training

\begin{tabular}{|l|c|c|}
\hline \multirow{2}{*}{} & \multicolumn{2}{|c|}{ Professional Training } \\
\cline { 2 - 3 } & Frequency & $\%$ \\
\hline Insufficient Training & 9 & 64.3 \\
Sufficient Training & 3 & 21.4 \\
Average Training & 1 & 7.1 \\
Not Trained At All & 1 & 7.1 \\
Total & 14 & 100.0 \\
\hline
\end{tabular}

\subsubsection{In Service Training}

In service training is a training given to those already in a profession with an aim of making them be in tandem with changes in the subject as it improves or with an aim of refreshing or improving their subject area. Data collected in relation to attendance of in service or orientation course in teaching of secondary CRE and its usefulness indicated that majority of teachers, 9 out of 14 (64.3\%), had attended in service training while $5(35.7 \%)$ had not attended any in-service course. 


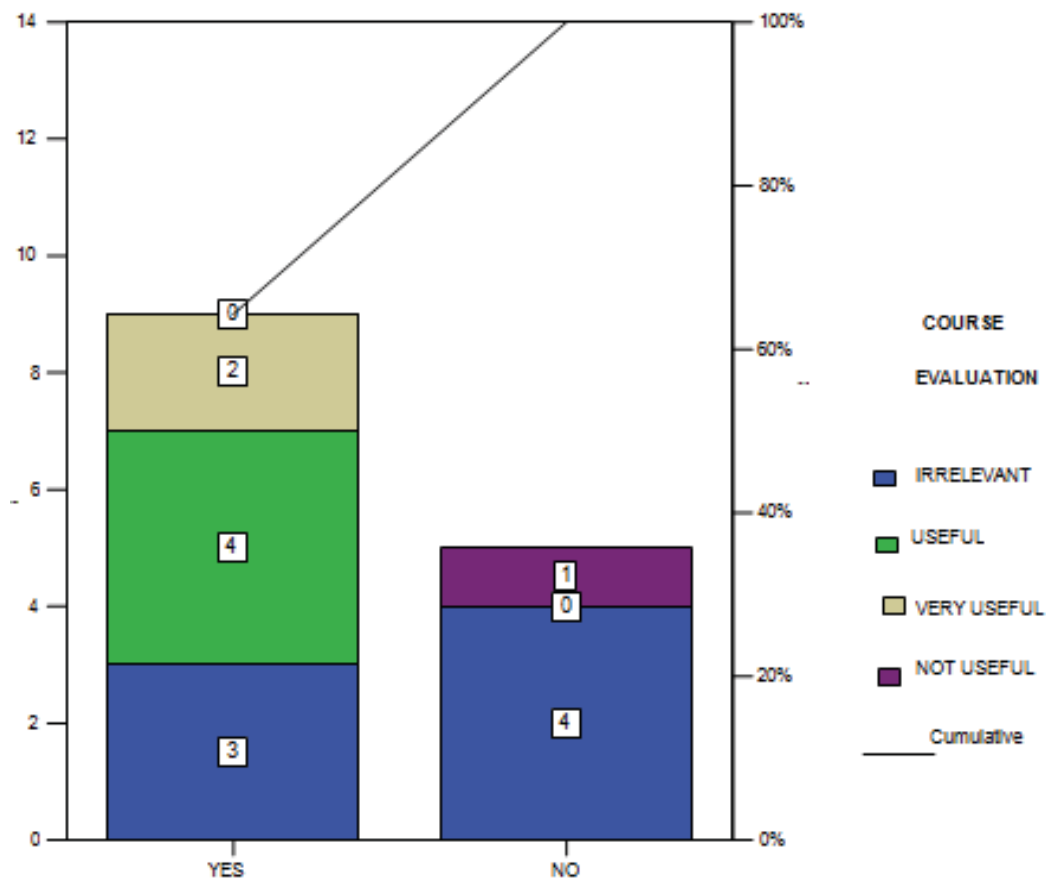

Fig 3. Inservice/Orientation Course

When asked issues discussed $28.6 \%$ pointed on curriculum innovations, while $25 \%$, indicated that the usefulness of these in-service training was to update teachers on CRE and subject issues like methodology of teaching performance improvement. This showed that in-service courses were offered regularly to update teachers on new approaches to the teaching

\section{Teaching Learning Strategies used by teachers of CRE}

The respondents were asked to list the methods they used in presenting CRE content and asked to rank the strategies in order of preference, citing which method they frequently used in their teaching.

\subsection{Methods used in lesson presentation}

In order for the researcher to identify the various methods, teachers of C.R.E were using in lesson presentation; the following data was collected as in Table 9.

Table 9: Methods used in lesson presentation

Method

Group work

Question and Answer

Individual presentation

Class Discussion

Story telling

TOTAL

Percentage
41.1
20.1
9.6
11.9
4.1
100.0


It can be observed that teachers of CRE were using a variety of Methods in presenting CRE content. $41.1 \%$ used group work, while $20.1 \%$ used question and answer method, only $9.6 \%$ used individual presentation, $11.9 \%$ used class discussion and $4.1 \%$ used story telling .only a very small percentage $3.2 \%$ used individual activity by the learners. From these findings it can be noted that the frequently used methods are question and answer and group Work. It is thus evident that such strategies as audio-visual, drama, role play, field trips and social action projects, least employed by the teachers in content presentation.

The findings were confirmed by the lesson observation checklists, where most respondents used lecture method, and question and answer method, most frequently thus least involving. Active learner participation and initiative, hence methods used did not involve discussion and learners experiences. The researcher also found out that what the respondents described as class discussion, was the learners participation in responding to the teachers questions, most of which called for simple recall of facts, or giving answers. Which the question answer method was mainly limited to yes or no answers. It was noted that the methods frequently used by teachers in content presentation were largely geared towards transmitting the content in the syllabus and rarely did they relate to the learner's real life situations.

Though table 4.9 Confirmed that $89.0 \%$ of the teachers used a variety of teaching methods. It is clear from the table that learner activity in lesson presentation was limited to discussion, note taking (18.3\%), bible reading (16.4\%) asking and answering questions (11.4\%) while individual learner activity and presentation only took $0.5 \%$ showing that active learner participation was minimal, and hence learning was more teacher centre and learners are never involved in practical activities to enable them respond.The researcher asked the respondents to give reasons why they preferred the choice of the strategy used frequently and most respondents argued that lecture method was the only way that would enable them cover the syllabus faster. And hence could not always involve the learners in the teaching learning process.

\subsection{Choice of teaching strategy}

The students were asked whether teachers imposed their views on them and as shown by table 4.10 students (71.7\%) confirmed that teachers imposed their views on them while only $62(28.3 \%)$ said no, an indication that the strategies used are mainly teacher centered leaving the learner with very little choice but depend on the teachers views.

\section{Constraints facing teachers of CRE using the Life Approach}

This section intended to find out whether the respondents encountered any problems in the use of life approach. Deductions of these were made using responses on the method content and presentation that teachers rarely used life approach in teaching CRE. Majority of the respondents said they used it sometimes. While others said they were not familiar with the method. The respondents stated difficulties encountered in teaching integrated C.R.E using life approach. The responses were presented in the table below.

Table 4.11: Difficulties Encountered by teachers of CRE

\begin{tabular}{|l|c|c|}
\hline \multirow{2}{*}{} & \multicolumn{2}{|c|}{$\begin{array}{c}\text { Difficulties in Teaching using } \\
\text { Life Approach }\end{array}$} \\
\cline { 2 - 3 } & Frequency & $\%$ \\
\hline Irrelevance & 6 & 42.9 \\
Time wastage & 1 & 7.1 \\
Inadequate time & 1 & 7.1 \\
Sensitive issues & 3 & 21.4 \\
Inadequate Teaching Resources & 2 & 14.3 \\
Others & 1 & 7.1 \\
Total & 14 & 100.0 \\
\hline
\end{tabular}

The findings revealed that teachers face a wide range of problems while teaching using the life approach strategy. Most (42.9\%) teachers felt that irrelevance, inadequacy of resources (14.3\%) and $21.4 \%$ felt teaching sensitive issues were more challenging. Many are the difficulties which were confirmed by the results of the interview schedule with the HOD's Humanities, who confirmed that teachers of CRE had reported some difficulties to them as shown in the table. 
From the responses, it is clear that teachers face number of constraints which inhibit them from using the life approach in teaching integrated CRE.

The recommendations, according to figure 4.3 most teachers (18\%) recommended that more relevant resource materials be provided if various difficulties were to be overcome. Those advocating for use of resource persons represented 49\%, while 4\% agreed that the CRE syllabus be reduced as it was too wide and gave teachers problems, overburdened the students and led to many learners to avoid CRE. Another group representing $4 \%$ argued that CRE should be made more compulsory in order to encourage more students to study it. A good proportion of teachers (7\%) saw guiding and counseling as the only way to make more students to opt for CRE. Other recommendations included use of resource persons, field trips (4\%) and provision of more teaching staff (7\%).

\section{Recommendations}

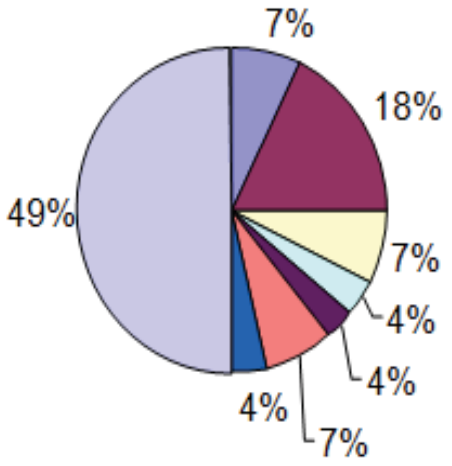

Figure 4. Solutions as Proposed by Respondents

\subsection{Observation checklist}

Lesson observation check list showed that teachers of CRE adequately prepared for their lessons in terms of content selection. The objectives of the lesson were clearly defined in behavioral terms and related well to the schemes of work and lesson plans in the class observed the objectives were clearly defined, however time allocated was inadequate(50\%). The teaching learning resources provided were inadequate and did not involve learner's active participation.

\subsection{Lessons introduction and presentation}

It was noted that $50 \%$ of the teachers observed introduced the lesson based on learner's experiences and that the introduction was $100 \%$. Relevant to the topic under discussion. However $50 \%$ of the teachers did not use variety of teaching learning resources which involved active learner participation. In the lesson presentation it was observed that most teachers 50\% frequently used lecturer method and question and answers method. They rarely used individual presentation and demonstration which both represented (25\%) of the responses respectively.

\subsection{Observation on Textbooks and Bible use}

The researcher found out that textbooks and bibles were $100 \%$ used by all the teachers while models, maps, and charts were rarely used reference to the bible was common to all classes observed with $100 \%$ of the teachers making reference to the bible. Out of the teaching learning resources used, only $50 \%$ were related to life approach. It was observed that involvement in practical activities during the lesson presentation was the minimal $25 \%$ with learners engaged in activities like listening, asking and answering questions as well as teacher directed discussions. 
Literature review in chapter two revealed that life approach is a key strategy in teaching integrated CRE in secondary schools since it involves the learners in the learning process and helps them to gain insight into unfolding of God's self revelation to human kind through their personal experience. However it is noted that most teachers do not use the life approach in the teaching of CRE, but they were found to be using methods which involve minimal learner's participation. The teachers of CRE under study were academically and professionally trained, though not adequately prepared during pre-service training to implement the new integrated CRE syllabus (1985) under the 8-4-4 system hence met challenges in teaching using life approach.

It is further evident from the findings that the teachers of CRE lacked adequate teaching learning resources to support the use of life approach in the teaching of the subject in secondary schools. Majority of the teachers indicated that they did not have adequate resources for the teaching of CRE, It was observed that apart from the chalkboard, the Bible and the recommended text-books, there were no other resources and hence the learners relied much on what the teacher had to say and give in the form of notes, which greatly deters the use of life approach. Not all teachers of CRE were using life approach in teaching integrated CRE. From the findings, it was observed that teachers were following the syllabus and content in the text book word for word, and made very few attempts to discuss the learners' day to day experiences. The implication of this is that learners were rarely involved in practical activities to enable them to respond to whatever they learned in the lesson.

The use of resource people and other community resources like places and other social action projects in the teaching of CRE established that learners did not make use of their experiences hence much of what is taught is theory, yet according to Evening(1994), the only way through which religious education can be made alive is by using life themes. Responses from respondents indicated that the bible is the main text book in CRE, majority of the respondents $195(89.0 \%)$ indicated that they frequently used the Bible in the teaching-learning process. Classroom observation also confirmed that the Bible was largely used in the lessons observed. This is an indication that the syllabus is still dominated by bible themes, and therefore teacher drew most of their examples from it minimizing the use of learner's day to day experiences.

\section{Conclusions}

From the foregoing findings of the study, the following conclusions are derived:

That teachers of CRE under study faced a number of constraints in using life approach strategy in teaching integrated CRE in secondary schools, which include inadequate time to involve learners in the discussion of their life experiences, too wide syllabus that prompted teachers to prefer lecture method, inadequate resources for effective implementation of integrated CRE using life approach strategy for example lack of audio-visual resources, finance to involve learners in field trips and other social action projects, learners.

Teachers of C.R.E were both academically and professionally qualified to teach integrated CRE using the life approach strategy. Most of them lack adequate pre-service and in-service training to fully implement the integrated C.R.E life approach teaching method. The most commonly used method in teaching integrated C.R.E was group discussions and lecture method which was mainly teacher centered. From the observation check list it was evident that most of the methods used in lesson presentation were not applicable to life approach strategy. Therefore the teachers of C.R.E need more in-service training in the use of the life approach strategy. Lack enough experiences to share and also insufficient guidance on how to use life approach in CRE by teachers due to insufficient training during-service and in service

\section{References}

Ayot, H.O.(1981). Approaches to school based in-service for effective teaching. A case Study of Kenyan Experience volume III Kenyatta University College, Nairobi

Ananda, D.A. (1990). Factors affecting the implementation of the 8-4-4 school Curriculum in primary schools. A survey of Emuhaya Division of Vihiga District. M.E.D (Unpublished). Thesis. Nairobi. Kenyatta University.

Bell, J. (1987). Doing a research project. A Guide for first time Researchers in Education and social sciences. London: Open University press.

Best, J.W. and Kahn, J.V (1993). Research in Education. Boston: Allyn and Bacon

Bishop, G. (1985). Curriculum Development: A textbook for students. London: Macmillan publishers.

Bruner J. (1966). Towards a Theory of Instruction. Cambridge, Massachusetts. Havard University Press.

(1970). Education of the Infant and young child. New York: Academic Press. 
(1976) .Human growth and development. U.K: oxford.

Chesaro, D.K (2003). Role of Christian religious Education in the moral development Of secondary school students in Rongai Division Nakuru. (Unpublished) Med Research project med Kenyatta University: Nairobi

COX .E. (1966) Changing aims in religious Education.London:Routledge and Kegan

Dewey, J. (1963). Experience and Education. U.S.A. Macmillan Company

Evening, M. (1974). Approaches for Religions Education. London: University of London press.

Gay, R.L. (1976). Educational research. Competing for Analysis and application Columbus: Charles E. Marvill Publishing Company a Bell and Howell Company.

Goble, N. and Porter, J. (1977). The changing role of the teacher. UNESCO, Paris.

Golby, M. (1983). Curriculum Design. Trowbrdge: Open University.

Goldman, R(1964), Religious Thinking from childhood to Adolescence, London: Routledge and Kegan Pul.

Grimitt; M.(1973). What can I do in Religious Education: A guide to New Approaches. London: Majhaw - Mc crimmon

Groenewegen; T. (1993). Subject methods Religious Education. A course book for Teachers, Nairobi, Lectern Publications.

Hawes, H. (1979). Curriculum and reality in African primary schools. Essex: Longman

Hellmot. R. L, Mc Beath, A, \& HERBERT, J. Robert.(1994). Teaching strategies and methods for student-centred instruction. USA

Holm, J. (1975). Teaches religion in school a practical approach Oxford University Press.

Kenya National Examinations council (1985). K.C.S.E regulations and syllabuses. Nairobi. Kenya national Examinations council

Kenya Institute of Education (1992) The Kenya certificate of secondary school syllabus for Christian religious Education, Nairobi. Jomo Kenyatta Foundation.

Kerlinger, F.N.(1973). Foundation of Behavioural research. New York: Holt, Rinehart and Uninston Inc.

Kerubo, J.O. (1994). The use of life Approach Method in Teaching Christian Religious Education in Schools in Nairobi, Thesis. Kenyatta University.

KIE .(2005) . Report on monitoring of the implementation of phase two of the Revised Secondary Education curriculum, July, 2005, Research report services no. 80 KIE Nairobi

Loukes, $\mathrm{H}(1965)$. New ground in Christian Education. London. SCM Press.

Loukes, N. (1961). Teenage religion .London SCM Press.

Republic of Kenya (1964). The Education Commission Report (Ominde Report). Government printer. Nairobi

Republic of Kenya (1976). Report of the National Committee on Educational objectives and policies. Government printer. Nairobi.

Republic of Kenya (1968). The Education Act. Government printer, Nairobi

Malusu, J.M.(1997). Role of the Christian church in curriculum development in Kenya. A case study of CISRET and CREATE in service teacher Education programmes (unpublished) Ph.D Thesis, Kenyatta University, Nairobi

Mugenda, O and Mugenda, A. (1999). Research methods: Qualitative and Quantative Approaches. Nairobi: Act press publishers.

Malusu, J.M. (1985). A study of problems affecting implementation of the New Christian religious Education Curriculum selected lower primary schools in Nairobi, Med thesis, Nairobi: Kenyatta University.

Muthoni; P. (1992). Adult catechesis in African context, (unpublished) Ph.D thesis, Nairobi: Nairobi catholic Higher Institute of Eastern Africa.

Wainaina. P.N. (1984). Teaching of Christian religious Education. Problems facing teachers in implementing the new Christian Religions Education Syllabus in the primary schools of Thika municipality, Unpublished M.ed thesis, Nairobi. University of Nairobi

Neil, S.C.( 1972). Religious Education in Revolution. Seminar study presented to the Council of higher studies in religion. Nairobi University of Nairobi.

Orodho, J.A (2005). Educational research for social sciences, Nairobi,Mazola publishers

Otiende ,J.E.(1982).Christian religious Education in Kenya. An assignment of the Evolution and operation of the western missionary Ideology, Unpublished PhD Thesis, Hull: Hull University.

Smart, N. (1968) . The Religious experience of Mankind. .Collins press Glasgow.

Talboid, A. (197). No one taught like this man. Nairobi: Jomo Kenyatta Foundation.

(2005). Techniques of writing research proposals and Reports.

Wittmer, J and Myrick, R.D (1974). Facilitative Teaching. Theory and practice. USA: Good year publishing Company Inc. 